\title{
Short-Time Derivatization Method for Analysis of Abamectin in Water Using High-Performance Liquid Chromatography Coupled to Fluorescence Detector
}

\author{
Daniela Cordeiro1, Luciana Teresa Dias Cappelini1 ${ }^{1}$, Raphael Teixeira Verbinnen ${ }^{1 *}$, \\ Gustavo Henrique Lourenço Vicente ${ }^{1}$, Andréa Novelli², Evaldo Luiz Gaeta Espíndola², \\ Eny Maria Vieira ${ }^{1}$ \\ ${ }^{1}$ Chemistry Institute of São Carlos, São Paulo University, São Carlos, Brazil \\ ${ }^{2}$ Center for Studies in Aquatic Ecosystems, São Paulo University, São Carlos, Brazil \\ Email: ${ }^{*}$ raphaeltv@hotmail.com
}

Received 14 September 2014; revised 29 October 2014; accepted 14 November 2014

Copyright (C) 2014 by authors and Scientific Research Publishing Inc.

This work is licensed under the Creative Commons Attribution International License (CC BY).

http://creativecommons.org/licenses/by/4.0/

c) (i) Open Access

\begin{abstract}
A method using a short-time derivatization step for the assessment of abamectin in water is presented. Abamectin derivative stable up to 7 days was obtained. Some regions where orange crops are present have received abamectin doses, aiming to increase the productivity and to combat pests and weeds, even when its residues reach the aquatic environment and interfere on water quality. Water samples from Jacaré-Pepira River (Brotas City, Brazil) nearby orange crops around urban zone, were evaluated for the presence of abamectin. The analytical method was validated resulting recovery around $108 \%$, precision of $12 \%$, accuracy of $104 \%$, correlation coefficient of 0.9945 , and detection and quantification limits of $0.1 \mu \mathrm{g} \cdot \mathrm{L}^{-1}$ and $0.2 \mu \mathrm{g} \cdot \mathrm{L}^{-1}$, respectively. Stable abamectin derivative was reached after $60 \mathrm{~min}$ of derivatization at room temperature $\left(25^{\circ} \mathrm{C}\right)$. No abamectin residues were found into samples.
\end{abstract}

Keywords

Abamectin, Derivatization, SPE, HPLC-FLD, Water

${ }^{*}$ Corresponding author.

How to cite this paper: Cordeiro, D., et al. (2014) Short-Time Derivatization Method for Analysis of Abamectin in Water Using High-Performance Liquid Chromatography Coupled to Fluorescence Detector. American Journal of Analytical Chemistry, 5, 1102-1108. http://dx.doi.org/10.4236/ajac.2014.516117 


\section{Introduction}

Avermectin $\mathrm{B}_{1}$ is a macrocyclic lactone naturally produced by actinomycete bacteria (Streptomyces avemitilis). It is a neurotoxin used as a pesticide in agriculture and as an acaricide and anthelminthic agent for livestock. Known as abamectin (ABA) in Brazil, it has high biological activity against parasites that attack different crops, being orange one of them [1]-[4]. The name abamectin refers to the mixture of two homologues (Figure 1), avermectin $\mathrm{B}_{1 \mathrm{a}}(\geq 80 \%)$ and avermectin $\mathrm{B}_{1 \mathrm{~b}}(\leq 20 \%)$ [5]. Both homologues degrade by oxidative and photooxidative processes, having half-lives shorter than $24 \mathrm{~h}$ in aquatic environments [3] [6]. The transformation product 8,9-Z-avermectin $\mathrm{B}_{1 \mathrm{a}}$, as well as avermectins $\mathrm{B}_{1 \mathrm{a}}$ and $\mathrm{B}_{1 \mathrm{~b}}$ are considered to be of toxicological importance [7]. The European Union [8] indicates ABA as an expression of the sum of those three substances and establishes maximum residue limits (MRLs) only in food, animal and vegetables matrix, with values ranging from 0.01 to $1.0 \mathrm{mg} \cdot \mathrm{kg}^{-1}$. Therefore, no environmental matrix is considered, such as in Brazil. The Brazilian Health Surveillance Agency (ANVISA) does not consider avermectin $\mathrm{B}_{1 \mathrm{~b}}$ an important residue to be controlled.

Liquid chromatography coupled to fluorescence detector (LC-FLD), ultraviolet detector (LC-UV) and mass spectrometer (LC-MS), as well as immunochemistry assays have been reported as analytical methods for avermectins analyses [9]-[11]. Most of them use a derivatization step while analyzing complex matrices, such as milk [11] [12]. Reemtsma et al. [10] developed a LC-MS method for determining ABA in water; however, no derivatization step was used. Recently, Novelli et al. [13] reported a study evaluating the abamectin toxicity to some organisms. ABA was quantified in aqueous solution using a method based on solid phase extraction followed by determination in high performance liquid chromatography couple to fluorescence detector (SPE/ HPLC-FLD).

Although the US-EPA adopted methods based on LC-FLD for analyzing those substances, many researchers [9] [12] reported difficulties mainly regarding the abamectin derivatization step. Avermectin $B_{1 a}$ and its isomer 8,9-Z-avermectin $\mathrm{B}_{1 \mathrm{a}}$ are converted to identical fluorescents derivatives in the presence of trifluoroacetic anhydride (TFAA), making the fluorescence detector unable to discriminate between them [14].

Among the analytical techniques used for the analyses of macrocyclic lactones, Berendsen et al. [12] and Danaher et al. [15] highlighted the selectivity and the sensitivity of HPLC-FLD and HPLC-MS. However, both authors reported problems with the analytes derivatization step, mostly regarding the derivatives stability and the length of this step in the sample preparation.

In comparison to older pesticides, abamectin is effective using lower doses; nevertheless, ecotoxicological assessments have found high ecotoxicity towards fishes [2] [3] [6]. Tisler and Erzen [6] assessed the abamectin ecotoxicity towards algae (Scenedesmus subspicatus), bacteria (Vibrio fischeri NRRL-B-11177), daphnids (Daphnia magna), and fishes (Danio rerio). According to the EU classification criteria for dangerous substances, the authors concluded that abamectin was highly toxic for aquatic organisms. In Brazil, Novelli et al. [13] reported that abamectin showed high ecotoxicity towards aquatic organisms, such as zooplankton (Daphnia similis), insects (Chironomus xanthus), and fishes (Danio rerio). Although the use of ABA has increased lately, mainly due to its attractive properties, there is little information about analytical methods for its identification in water [13] [16] [17].

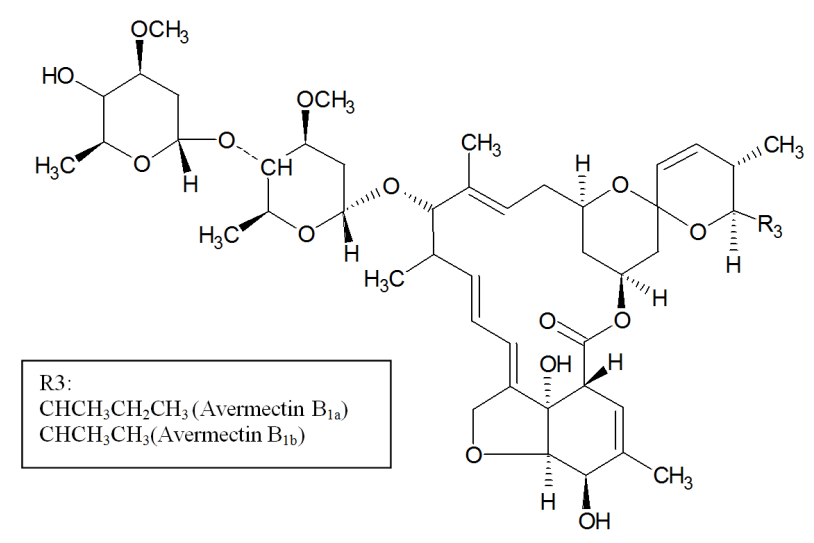

Figure 1. Molecular structure of avermectins. 
In 2008, Brotas (São Paulo, Brazil), a city located in the studied region, had around 6 million orange trees, being the $5^{\text {th }}$ largest cultivated area in São Paulo State, Brazil [4].

This paper describes a method for analyzing abamectin in surface natural waters and proposes an alternative derivatization step, which is faster and less energy-consuming, in comparison to others studies [15]. The method is applied in a region known by its ecotourism and aquatic activities in the Jacaré-Pepira River, whose watershed has a large number of orange crops.

\section{Methodology}

Triethylamine (TEA), tetrahydrofuran (THF) 1-methylimidazole (1MI, 299\%), and abamectin (ABA, 99\%) were purchased from Sigma-Aldrich (St. Louis, MO, USA). Trifluoroacetic anhydride (TFAA) and dichloromethane (DCM) were purchased from Merck (Darmstadt, Germany) and Mallinckrodt Baker (Phillipsburg, NJ, USA), respectively. Previous reagents were of analytical grade. Ultrapure water $\left(18.2 \mathrm{M} \Omega \cdot \mathrm{cm}\right.$ at $\left.25^{\circ} \mathrm{C}\right)$ was obtained from a Milli-Q water purification system (Millipore Corporation, Billerica, MA, USA). SPE cartridges containing $500 \mathrm{mg}$ of octadecylsilane (C-18, SampliQ series) adsorbents were purchased from Agilent Technologies $^{\circledR}$ (West Lothan, UK). Stock and working solutions were prepared in acetonitrile (ACN) HPLC grade purchased from Merck (Darmstadt, Germany) and stored at $-20^{\circ} \mathrm{C}$.

\subsection{Chromatographic Settings}

A high performance liquid chromatography device coupled to a fluorescence detector (HPLC-FLD, Agilent Technologies ${ }^{\circledR} 1200$ series, Waldbronn, Germany) was used to analyze abamectin, with a Partisil 5 ODS-3 column $\left(250 \times 4.6 \mathrm{~mm}, 5 \mu \mathrm{m}\right.$, Whatman $\left.{ }^{\circledR}\right)$, at a controlled temperature of $25^{\circ} \mathrm{C}$. The excitation and emission wavelengths were 364 and $475 \mathrm{~nm}$, respectively. An isocratic mobile phase comprised of $\mathrm{ACN}: \mathrm{H}_{2} \mathrm{O}: \mathrm{THF}$ (80:14:6, in volume) was used, with a flow rate of $1.0 \mathrm{~mL} \cdot \mathrm{min}^{-1}$ and a run time of $14 \mathrm{~min}$. The injection volume was $100 \mu \mathrm{L}$.

\subsection{Sampling and Sample Preparation}

Solid phase extraction (SPE) was used to prepare the sample prior to ABA determination with HPLC-FLD. Ultrapure water was used to prepare the spiked samples employed in the SPE development and method validation.

Surface water samples from the Jacaré-Pepira River were collected at four different points downstream, near to orange crops and the urban zone, sites where ABA could be used (Table 1 and Figure 2). Dark glass bottles $(1 \mathrm{~L})$ were used to collect water samples, at a depth around $50 \mathrm{~cm}$. Those bottles were previously washed with neutral detergent, tap water, and ultrapure water, sequentially.

Sample preparation started with the filtration of $200 \mathrm{~mL}$ of the samples through cellulose acetate membranes $\left(0.45 \mu \mathrm{m} \times 47 \mathrm{~mm}\right.$, Millipore ${ }^{\circledR}$, Brazil). Afterwards, it was percolated through an SPE cartridge containing C-18 adsorbent (500 mg), previously conditioned with $10 \mathrm{~mL}$ ACN and $5 \mathrm{~mL} \mathrm{ACN}: \mathrm{H}_{2} \mathrm{O}: \mathrm{TEA}$ (30:70:0.2, in volume). Then, the adsorbent was dried for $3 \mathrm{~min}$ and the analytes were eluted, into an amber flask, using $20 \mathrm{~mL}$ DCM. Except for filtration, all the other steps were held under $15 \mathrm{kPa}$ vacuum. The eluate was dried under a gentle $\mathrm{N}_{2}$ stream and reconstituted by adding $1 \mathrm{~mL}$ ACN to the flask. This extract was transferred to an amber $2 \mathrm{~mL}$-vial wrapped in aluminum foil.

Table 1. Information of the sampled points.

\begin{tabular}{|c|c|c|c|c|}
\hline Information & Point 1 & Point 2 & Point 3 & Point 4 \\
\hline Date & 09/03/2010 & 09/03/2010 & 09/03/2010 & 09/03/2010 \\
\hline Time & $9: 55$ & $10: 30$ & $11: 13$ & $11: 51$ \\
\hline Coordinates & $\begin{array}{c}22.26309^{\circ} \mathrm{S} \\
48.22975^{\circ} \mathrm{W}\end{array}$ & $\begin{array}{c}22.29144^{\circ} \mathrm{S} \\
48.12938^{\circ} \mathrm{W}\end{array}$ & $\begin{array}{c}22.28438^{\circ} \mathrm{S} \\
48.10722^{\circ} \mathrm{W}\end{array}$ & $\begin{array}{r}22.30025^{\circ} \mathrm{S} \\
48.11026^{\circ} \mathrm{W}\end{array}$ \\
\hline $\mathbf{p H}$ & 6.98 & 7.25 & 6.60 & 7.11 \\
\hline Condutivity $\left(\mathrm{mS} \cdot \mathrm{cm}^{-1}\right)$ & 0.033 & 0.031 & 0.019 & 0.032 \\
\hline Turbidity (uT) & 10 & 10 & 10 & 10 \\
\hline Dissolved oxygen $\left(\mathrm{mg} \cdot \mathrm{L}^{-1}\right)$ & 9.75 & 8.25 & 8.25 & 6.02 \\
\hline Temperature $\left({ }^{\circ} \mathrm{C}\right)$ & 21.7 & 21.9 & 21.9 & 22.2 \\
\hline Salinity (\%) & 0 & 0 & 0 & 0 \\
\hline
\end{tabular}




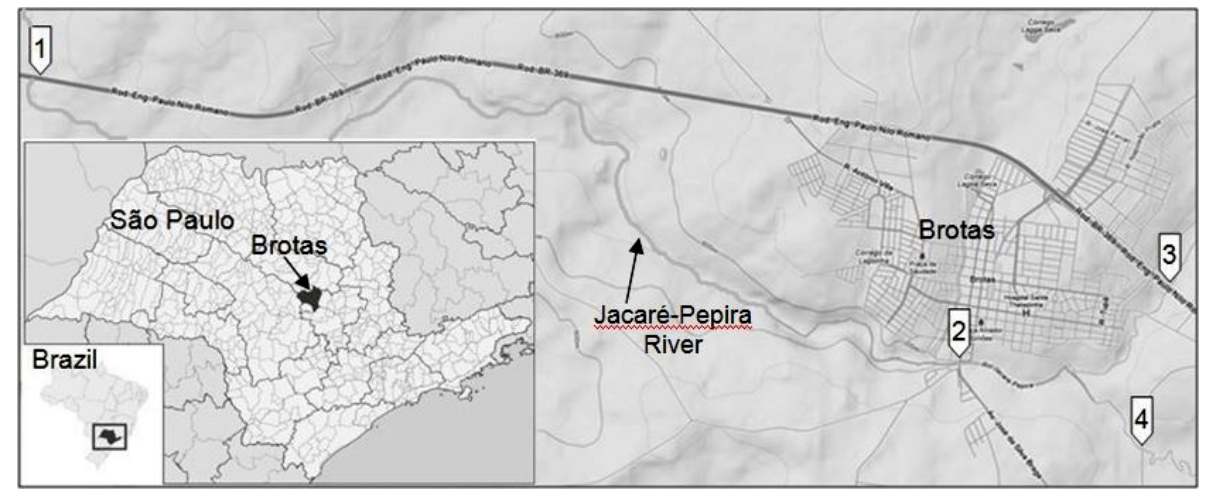

Figure 2. Sample points (1, 2, 3, and 4) in Jacaré-Pepira River, surrounding Brotas City.

\subsection{Abamectin Derivatization Step}

The derivatization step of ABA took place by adding $200 \mu \mathrm{L} 1 \mathrm{MI}$ and $200 \mu \mathrm{L}$ ACN:TFAA (2:1, in volume) to the vial. After $60 \mathrm{~min}$ at room temperature $\left(25^{\circ} \mathrm{C}\right), 100 \mu \mathrm{L}$ of the sample was introduced into the chromatographic system.

During method development and prior to validation, all samples preparation steps were performed with ultrapure water spiked with ABA concentrations ranging from 0.2 to $10.0 \mu \mathrm{g} \cdot \mathrm{L}^{-1}$.

\subsection{Method Validation}

Method validation assessed the parameters: selectivity, limit of quantification (LOQ), limit of detection (LOD), linearity, accuracy, precision, and recovery. The latter was performed using ultrapure water spiked with ABA concentrations of $0.2,1.0$, and $5.0 \mu \mathrm{g} \cdot \mathrm{L}^{-1}$, in three replicates each one and according to the sample preparation described in Section 2.2.

Precision was calculated dividing the standard deviation (SD) of the instrumental responses (peak areas) by their average. Recovery was set as the peak area obtained for a spiked sample, divided by the peak area of the analyte standard solution. Accuracy was calculated in the same way, but the peak areas were previously turned into concentrations through the linearity equation of the method. The calculations regarded only the peak for avermectin $\mathrm{B}_{1 \mathrm{a}}$ due to its greater intensity in the HPLC-FLD analysis.

LOD was considered the concentration at which the abamectin signal was three times larger than the noise from the chromatogram baseline. LOQ was the concentration at which the analyte signal was five times higher than that noise.

\section{Results and Discussion}

In this study, a simple derivatization method, without heating, was used to provide derivatives with stability twice greater than the largest duration reported by Danaher et al. [15]. The repeatability of the method is obtained using less energy (no heat) and shorter times (60 min).

The derivatization duration was a critical step of the method. 15 min of reaction yielded chromatographic peaks with variable areas. Therefore, 30, 45, and $60 \mathrm{~min}$ of the derivatization reaction were tested. Among them, only a 60 min reaction yielded peaks stable enough during at least 7 days, after which a decrease of the analyte concentration was observed. Considering the total reaction time and the decrease of the derivative concentration after 7 days, it is believed that trifluoroacetyl ester (flu-TFA) derivative was the chromophore compound formed. Berendsen et al. [12] reported that flu-TFA was the most stable abamectin derivative in such reaction.

The validation results, LOD, and LOQ are shown in Table 2. The method selectivity and the retention times of avermectin $B_{1 a}(10.4 \mathrm{~min})$ and avermectin $B_{1 b}(9.3 \mathrm{~min})$ can be observed in Figure 3 . It shows that no interfering signals from the sample matrix occurred in the same retention times of the analytes.

A procedure for the derivatization of abamectin was established at room temperature $\left(25^{\circ} \mathrm{C}\right)$ and during 60 min. Although the sampling points were located downstream and near some orange crops, ABA residues were not found in any of the samples analyzed (Figure 4). Similar works, performed in the same studied region, could not be found. Probably, abamectin residues are in concentrations below the method LOD. 
Table 2. Validation data.

\begin{tabular}{cc}
\hline Parameters & Results (n= 5) \\
\hline Recovery $^{*}$ & $75 \%, 87 \%, 109 \%$ \\
Limit of detection (LOD) $^{-1}$. & $0.1 \mu \mathrm{g} \cdot \mathrm{L}^{-1}$ \\
Limit of quantification (LOQ) & $0.2 \mu \mathrm{g} \cdot \mathrm{L}^{-1}$ \\
Linearity & $\mathrm{Y}=8.38+615.56 \mathrm{X}$ \\
Determination coefficient $\left(\mathrm{R}^{2}\right)$ & 0.9945 \\
Precision (RSD—relative standard deviation) & $12 \%$ \\
Accuracy & $104 \%$ \\
\hline
\end{tabular}

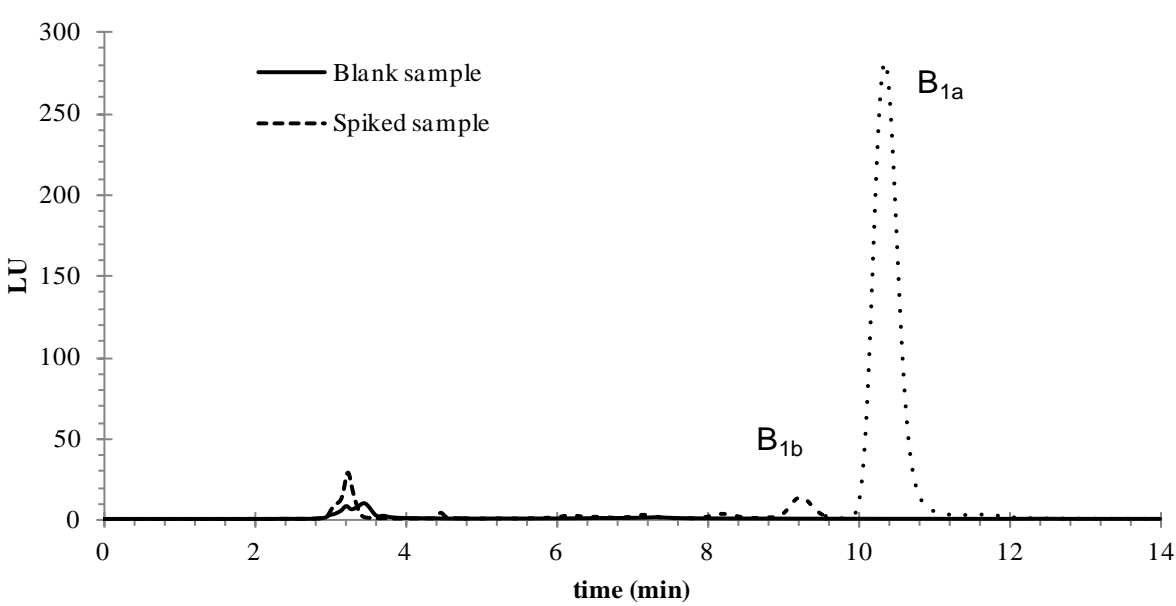

Figure 3. Method selectivity chromatogram comparing the blank matrix sample (-) to a 10 $\mu \mathrm{g} \cdot \mathrm{L}^{-1}$ spiked matrix sample (---). Chromatographic conditions: $\mathrm{H}_{2} \mathrm{O}$ :ACN:THF (14:80:6, in volume), isocratic mode, column temperature of $25^{\circ} \mathrm{C} \pm 0.5^{\circ} \mathrm{C}$, flow rate of $1 \mathrm{~mL} \cdot \mathrm{min}^{-1}$, injection volume of $100 \mu \mathrm{L}$, excitation $\lambda=364 \mathrm{~nm}$, emission $\lambda=475 \mathrm{~nm}$.

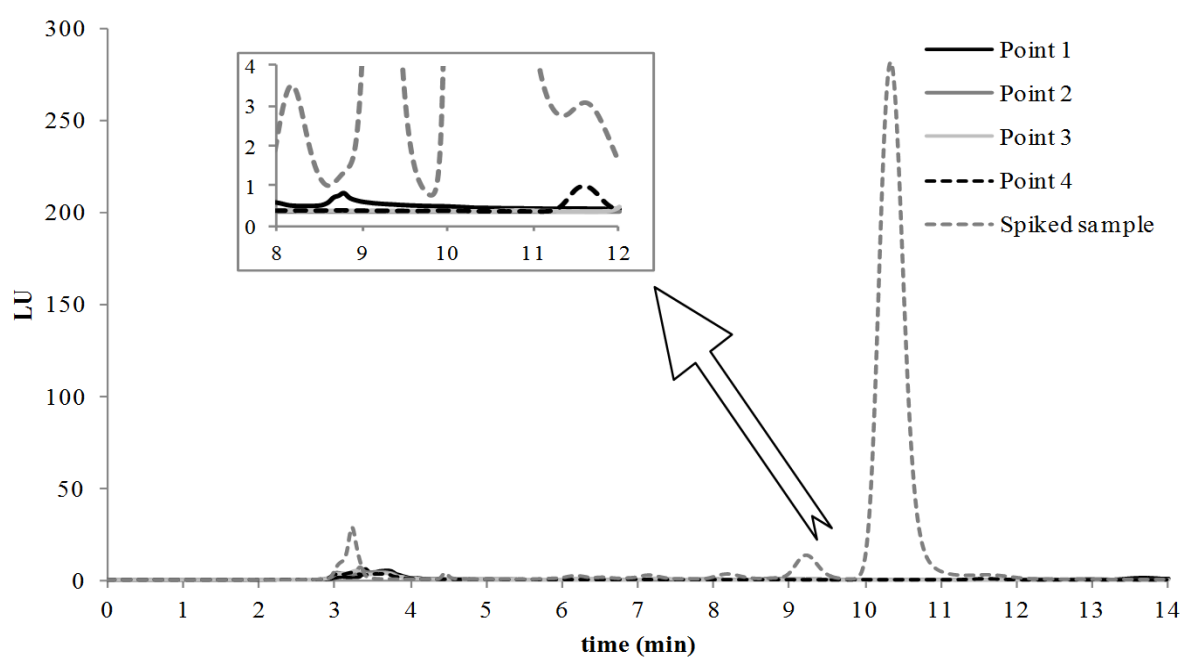

Figure 4. Chromatograms comparing the signals of the sampled points to a $10 \mu \mathrm{g} \cdot \mathrm{L}^{-1}$ spiked sample (---). Chromatographic conditions: $\mathrm{H}_{2} \mathrm{O}$ :ACN:THF (14:80:6, in volume), isocratic mode, flow rate of $1 \mathrm{~mL} \cdot \mathrm{min}^{-1}$, injection volume of $100 \mu \mathrm{L}$, excitation $\lambda=364 \mathrm{~nm}$, emission $\lambda$ $=475 \mathrm{~nm}$, column temperature of $25^{\circ} \mathrm{C} \pm 0.5^{\circ} \mathrm{C}$.

\section{Conclusion}

A procedure, at a room temperature and during $60 \mathrm{~min}$, able to produce a stable abamectin derivative for seven 
days was established, making it easy and fast for the analysis of abamectin in water. These method characteristics are the innovation presented in this paper. Abamectin residues were not found at concentrations comprised by the method, even though the assessed region was surrounded by orange crops. That occurs, in part, because abamectin residues have high degradation rates, almost disappearing within $48 \mathrm{~h}$. The method presented here improves the analysis of abamectin in water, decreasing its running time and ensuring the repeatability of its results. This is a pioneer work in the studied region.

\section{Acknowledgements}

The authors thank the Coordination for the Improvement of Higher Education Personnel (CAPES), the National Council for Scientific and Technological Development (CNPq), and the São Paulo State Research Foundation (FAPESP).

\section{References}

[1] Valenzuela, A.I., Popa, D.S., Redondo, M.J. and Mañes, J. (2001) Comparison of Various Liquid Chromatographic Methods of Avermectin Residues in Citrus Fruits. Journal of Chromatography A, 918, 59-65. http://dx.doi.org/10.1016/S0021-9673(01)00737-3

[2] Brewer, B.N., Armbrust, K.L., Mead, K.T. and Holmes, W.E. (2004) Determination of Abamectin in Soil Samples Using HPLC-MS/MS. Rapid Communications in Mass Spectrometry, 18, 1693-1696. http://dx.doi.org/10.1002/rcm.1537

[3] Jenčič, V., Černe, M., Eržen, N.K., Kobal, S. and Cerkvenik-Flajs, V. (2006) Abamectin Effects on Rainbow Trout (Oncorhynchus mykiss). Ecotoxicology, 15, 249-257. http://dx.doi.org/10.1007/s10646-006-0056-6

[4] São Paulo (Estado) (2008) Instituto de Economia Agrícola. Levantamento censitário de unidades de produção agrícola do Estado de São Paulo—LUPA 2007/2008. SAA/CATI/IEA, São Paulo. http://www.cati.sp.gov.br/projetolupa

[5] Tomlin, C.D.S. (1994) The Pesticide Manual: Incorporating the Agrochemicals Handbook. British Crop Protection Council, The Royal Society of Chemistry, Cambridge.

[6] Tisler, T. and Erzen, N.K. (2006) Abamectin in the Aquatic Environment. Ecotoxicology, 15, 495-502. http://dx.doi.org/10.1007/s10646-006-0085-1

[7] United States (2012) EPA Index of Residue Analytical Methods (RAM). http://www.epa.gov/pesticides/methods/ram12b.htm\#A

[8] European Union (2007) Commission Directive 2007/7/EC of 14 February 2007 Amending Certain Annexes to Council Directives 86/362/EEC and 90/642/EEC. Official Journal of the European Union, L43, 19.

[9] Raich-Montiu, J., Krogh, K.A., Granados, M., Jönsson, J.Å. and Halling-Sørensen, B. (2008) Determination of Ivermectin and Transformation Products in Environmental Waters Using Hollow Fibre-Supported Liquid Membrane Extraction and LC-MS/MS. Journal of Chromatography A, 1187, 275-280. http://dx.doi.org/10.1016/j.chroma.2008.02.063

[10] Reemtsma, T., Aldera, L. and Banasiak, U. (2013) A Multimethod for the Determination of 150 Pesticide Metabolites in Surface Water and Groundwater Using Direct Injection Liquid Chromatography-Mass Spectrometry. Journal of Chromatography A, 1271, 95-104. http://dx.doi.org/10.1016/j.chroma.2012.11.023

[11] Campillo, N., Viñas, P., Férez-Melgarejo, G. and Hernández-Córdoba, M. (2013) Dispersive Liquid-Liquid Microextraction for the Determination of Macrocyclic Lactones in Milk by Liquid Chromatography with Diode Array Detection and Atmospheric Pressure Chemical Ionization Ion-Trap Tandem Mass Spectrometry. Journal of Chromatography A, 1282, 20-26. http://dx.doi.org/10.1016/j.chroma.2013.01.086

[12] Berendsen, B.J.A., Mulder, P.P.J. and Van Rhijn, H.J.A. (2007) The Derivatisation of Avermectins and Milbemycins in Milk: New Insights and Improvement of the Procedure. Analytica Chimica Acta, 585, 126-133. http://dx.doi.org/10.1016/j.aca.2006.12.013

[13] Novelli, A., Vieira, B.H., Cordeiro, D., Cappelini, L.T.D., Vieira, E.M. and Espíndola, E.L.G. (2012) Lethal Effects of Abamectin on the Aquatic Organisms Daphnia similis, Chironomus xanthus and Danio rerio. Chemosphere, 86, 36-40. http://dx.doi.org/10.1016/j.chemosphere.2011.08.047

[14] Hernández-Borges, J., Ravelo-Pérez, L.M., Hernández-Suárez, E.M., Carnero, A. and Rodríguez-Delgado, M.A. (2007) Analysis of Abamectin Residues by High-Performance Liquid Chromatography with Fluorescence Detection. Journal of Chromatography A, 1165, 52-57. http://dx.doi.org/10.1016/j.chroma.2007.07.033

[15] Danaher, M., Howells, L.C., Crooks, S.R.H., Cerkvenik-Flajs, V. and O’Keeffe, M. (2006) Review of Methodology for the Determination of Macrocyclic Lactone Residues in Biological Matrices. Journal of Chromatography B, 844, 175- 
203. http://dx.doi.org/10.1016/j.jchromb.2006.07.035

[16] Krogh, K.A., Björklund, E., Loeffler, D., Fink, G., Halling-Sørensen, B. and Ternes, T.A. (2008) Development of an Analytical Method to Determine Avermectins in Water, Sediments and Using LC-MS. Journal of Chromatography A, 1211, 60-69. http://dx.doi.org/10.1016/j.chroma.2008.09.081

[17] Hernando, M.D. and Suárez-Barcena, J.M. (2007) Fast-Separation LC-MS and Quantitative Analysis of Avermectin Residues in Food. Journal of Chromatography A, 1155, 62-73. http://dx.doi.org/10.1016/j.chroma.2007.02.120 
Scientific Research Publishing (SCIRP) is one of the largest Open Access journal publishers. It is currently publishing more than 200 open access, online, peer-reviewed journals covering a wide range of academic disciplines. SCIRP serves the worldwide academic communities and contributes to the progress and application of science with its publication.

Other selected journals from SCIRP are listed as below. Submit your manuscript to us via either submit@scirp.org or Online Submission Portal.
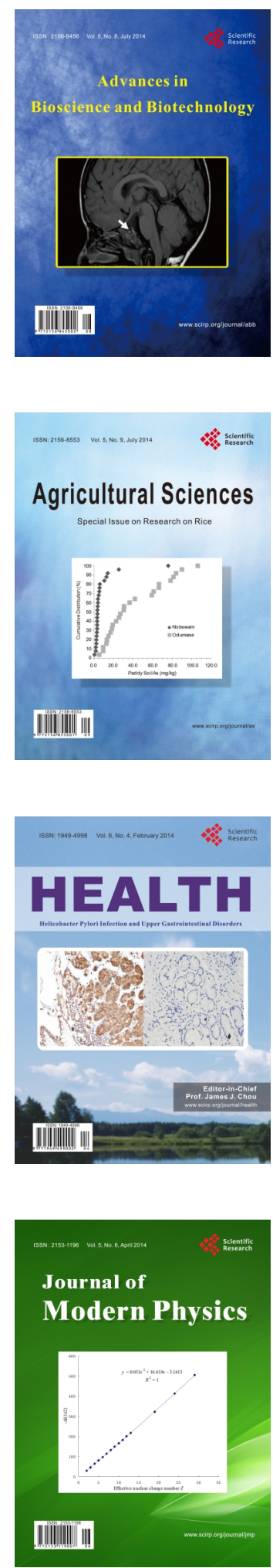
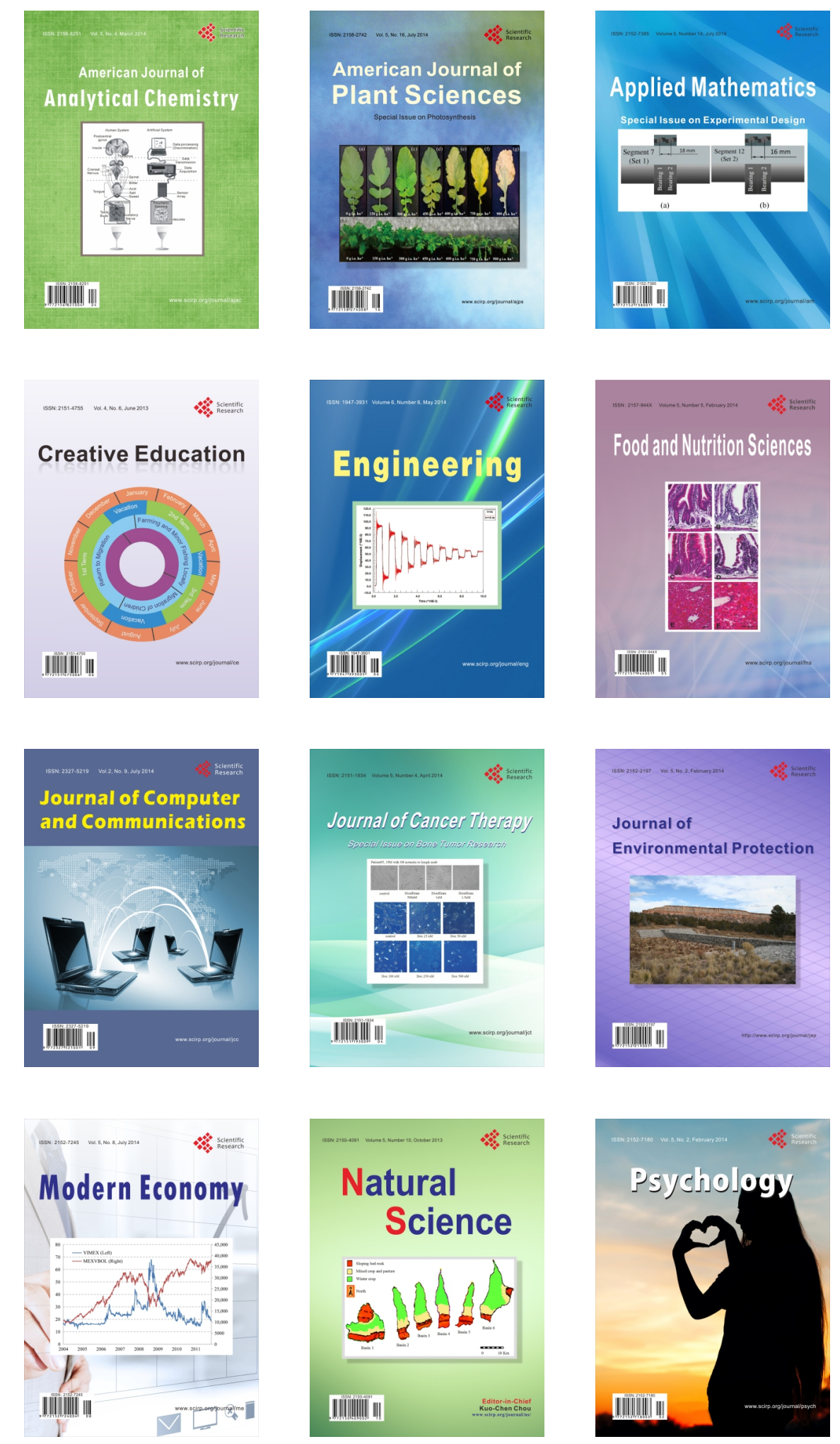